\title{
CHEMICAL, CLINICAL, AND IMMUNOLOGICAL STUDIES ON THE PRODUCTS OF HUMAN PLASMA FRACTIONATION. XXXVI. INACTIVATION OF THE VIRUS OF HOMOLOGOUS SERUM HEPATITIS IN SOLUTIONS OF NORMAL HUMAN SERUM ALBUMIN BY MEANS OF HEAT 1, 2
}

\author{
By SYDNEY S. GELLIS, JOHN R. NEEFE, ${ }^{3}$ JOSEPH STOKES, JR., LAWRENCE \\ E. STRONG, CHARLES A. JANEWAY, AND GEORGE SCATCHARD \\ (From the Children's Hospital and Department of Pediatrics, the University of Pennsylvania; \\ the Departments of Physical Chemistry and Pediatrics, Harvard Medical School; \\ and the Department of Chemistry, Massachusetts Institute of Technology)
}

(Received for publication November 10, 1947)

The extensive administration of whole blood, plasma, and serum in the past few years has made the problem of homologous serum hepatitis an important one. The 23,000 cases of hepatitis in Armed Forces personnel (1) resulting from the injection of certain lots of yellow fever vaccine which had been stabilized with human serum gave great impetus to study of the disease in this country.

Most epidemiological investigations suggest strongly that the risk of transmitting hepatitis is greater with plasma than with whole blood (2). This presumably depends on the practice of pooling the plasma from a number of donors, an occasional one of whom may harbor the virus, and of administering each pool to multiple recipients.

In the preparation of pooled plasma for the Armed Services from blood collected by the American Red Cross during the war, the size of the pools was set at 25 or 50 bloods depending upon final distribution in packages of $250 \mathrm{ml}$. or of $500 \mathrm{ml}$. In the preparation of normal human serum albumin, similarly collected pools of plasma representing from 250 to 2,000 bloods were used as starting material for the process of plasma frac-

\footnotetext{
1 This study was carried out under the Commission on Measles and Mumps, Army Epidemiological Board, Preventive Medicine Service, Office of the Surgeon General, U. S. Army, Washington, D. C., and under contracts, recommended by the Committee on Medical Research, between the Office of Scientific Research and Development and Harvard University.

2 This paper is No. 70 in the series of studies on Plasma Proteins from the Department of Physical Chemistry, Harvard Medical School, Boston, Massachusetts, on products developed by the Department of Physical Chemistry from bloods collected by the American Red Cross.

${ }^{3}$ National Research Council Senior Fellow in the Medical Sciences.
}

tionation. The large size of these pools made it seem probable that a considerable number of them would be contaminated with the virus of homologous serum hepatitis. This was a source of great concern to those directly involved in the plasma fractionation program and to the subcommittee on Blood Substitutes of the National Research Council. Consequently, efforts were made to develop methods for the inactivation of hepatitis virus in solutions of normal human serum albumin.

The hepatitis viruses are known to be highly resistant to chemical and physical agents. They survive heating at $56^{\circ} \mathrm{C}$ for one hour (3), a temperature usually employed for the inactivation of viruses. They remain active for at least several years in the frozen state and withstand repeated thawing and refreezing (4). In desiccated yellow fever vaccine, the icterogenic property was still present after at least one year of storage at room temperature (5). Hepatitis viruses in plasma have remained active in the presence of merthiolate in a concentration of $1: 2000$ (6), equal parts of phenol and ether in a $0.5 \%$ concentration ( 7$)$, tricresol in a $0.2 \%$ concentration (8), and chlorine in excess of that required to destroy the pathogenic bacteria commonly found in drinking water (9).

The remarkable thermal stability of normal human serum albumin solutions suggested the use of heat as the most likely method for the inactivation of the hepatitis virus. It was clear that the temperature required to inactivate the virus of hepatitis would be relatively high. It was therefore necessary to select conditions as rigorous as possible in order to obtain the greatest chance of destroying the virus, yet within limits which albumin solutions could withstand. The investigations 
of Luck and his associates on stabilization (10, 11) and of Scatchard and his co-workers on the development of low-salt albumin (12) revealed that the addition of certain non-polar anions to solutions of albumin would markedly increase their thermal stability. The use of $0.04 \mathrm{M}$ acetyltryptophane as a diluent resulted in an albumin solution which could be heated for 10 hours at $60^{\circ}$ $\mathrm{C}$ without decreasing its stability below that of unheated standard preparations in which $0.3 \mathrm{M}$ $\mathrm{NaCl}$ was the diluent. Consequently, this duration and degree of heating were agreed upon for trial. Since even higher temperatures could be attained by the use of larger amounts and different combinations of stabilizing reagents, it was also decided to test the effect of a 10-hour period at $64^{\circ} \mathrm{C}$, using $0.02 \mathrm{M}$ sodium caprylate in addition to $0.04 \mathrm{M}$ acetyltryptophane to further enhance stability.

\section{PROCEDURE}

Owing to the lack of known susceptible laboratory animals, human volunteers must be inoculated in order to demonstrate the presence of active hepatitis virus in a given material. Because of the scarcity of volunteers, only limited experiments could be conducted. Plasma previously proven on repeated occasions to contain a virus of homologous serum hepatitis (5) was selected for addition to the albumin solution to be treated and tested. A 25\% solution of normal human serum albumin from a single lot was prepared for this experiment, one portion containing $0.04 \mathrm{M}$ acetyltryptophane, and another portion 0.04 acetyltryptophane and $0.02 \mathrm{M}$ sodium caprylate.

The icterogenic plasma which had been kept frozen at $-70^{\circ} \mathrm{C}$ was shipped from Philadelphia to Boston on dry ice. It was thawed at $37^{\circ} \mathrm{C}$ and divided into 3 portions which were treated as follows:

Mixture $A$ (control) : Ten ml. of plasma were mixed with $40 \mathrm{ml}$. of $25 \%$ human serum albumin solution stabilized with $0.04 \mathrm{M}$ acetyltryptophane. This mixture was stored in a tightly stoppered vaccine vial in the refrigerator until the heating of mixtures $\mathrm{B}$ and $\mathrm{C}$ was completed.

Mixture B: A mixture of $10 \mathrm{ml}$. plasma and $40 \mathrm{ml}$. of $25 \%$ albumin solution stabilized with $0.04 \mathrm{M}$ acetyltryptophane was prepared in a tightly stoppered sterile vaccine vial. This was completely submerged in a water bath at $60^{\circ} \mathrm{C}$ for 10 hours.

Mixture C: A mixture of $10 \mathrm{ml}$. of plasma with 40 $\mathrm{ml}$. of $25 \%$ albumin solution stabilized with $0.04 \mathrm{M}$ acetyltryptophane and $0.02 \mathrm{M}$ sodium caprylate was prepared in a tightly stoppered vaccine vial. This was completely submerged in a waterbath at $64^{\circ} \mathrm{C}$ for 10 hours.

Following the period of heating, Mixtures A, B, and C were promptly frozen with dry ice and shipped in the frozen state overnight to Trenton, N. J., where they were thawed at $37^{\circ} \mathrm{C}$ and injected on the same day. Fifteen volunteers were divided into 3 groups of 5 men each. Group I received Mixture A, Group II Mixture B, and Group III Mixture C. Each man was given $10 \mathrm{ml}$. of the material by intramuscular injection. The following liver function studies were carried out in all the volunteers according to standard methods already published (13) : urine bilirubin, urine urobilinogen, serum bilirubin, bromsulphalein retention, cephalin-cholesterol flocculation, serum colloidal gold and thymol turbidity. Urine determinations were carried out daily and serum determinations were performed once or twice weekly from a period of at least one month prior to injection until termination of the experiment 7 months after injection. If positive findings developed, all procedures were performed daily.

\section{RESULTS}

The results of the experiment are presented in Table I. Three of the five volunteers in the control group (I) which received the unheated mixture (A) of icterogenic plasma and albumin developed hepatitis, whereas none of the volunteers (Groups II and III) inoculated with the heated mixtures ( $B$ and $C$ ) showed laboratory changes suggestive of hepatitis. In Figure 1A, B, and C are given the laboratory findings of the three men in Group I who developed hepatitis but without clinical jaundice.

The experiment indicates that heating for 10 hours at either $60^{\circ} \mathrm{C}$ or $64^{\circ} \mathrm{C}$ appeared to be adequate to inactivate this hepatitis virus in human albumin solutions. The effectiveness of this temperature for shorter periods of time or the

TABLE I

Results of the inoculation of volunteers with mixtures of icterogenic plasma and human serum albumin solutions

\begin{tabular}{c|c|c|c}
\hline Group & Subject & Age & Hepatitis \\
\cline { 2 - 3 } $\begin{array}{c}\text { I } \\
\text { (Unheated }\end{array}$ & J. H. & 33 & + \\
mixture) & D. D. & 36 & + \\
& A. P. & 25 & \pm \\
\hline E. H. & 30 & - \\
AI & A. D. & 32 & - \\
(Mixture & L. V. & 35 & - \\
hea ted for & A. T. & 34 & - \\
10 hours & R. M. & 23 & - \\
at $60^{\circ}$ C) & P. J. & 22 & - \\
\hline H. B. & 33 & - \\
III & C. R. & 32 & - \\
(Mixture & W. B. & 28 & - \\
heated for & A. M. & 29 & - \\
10 hours & E. G. & 29 & - \\
at $64^{\circ}$ C) & A. C. & 31 & - \\
\hline
\end{tabular}



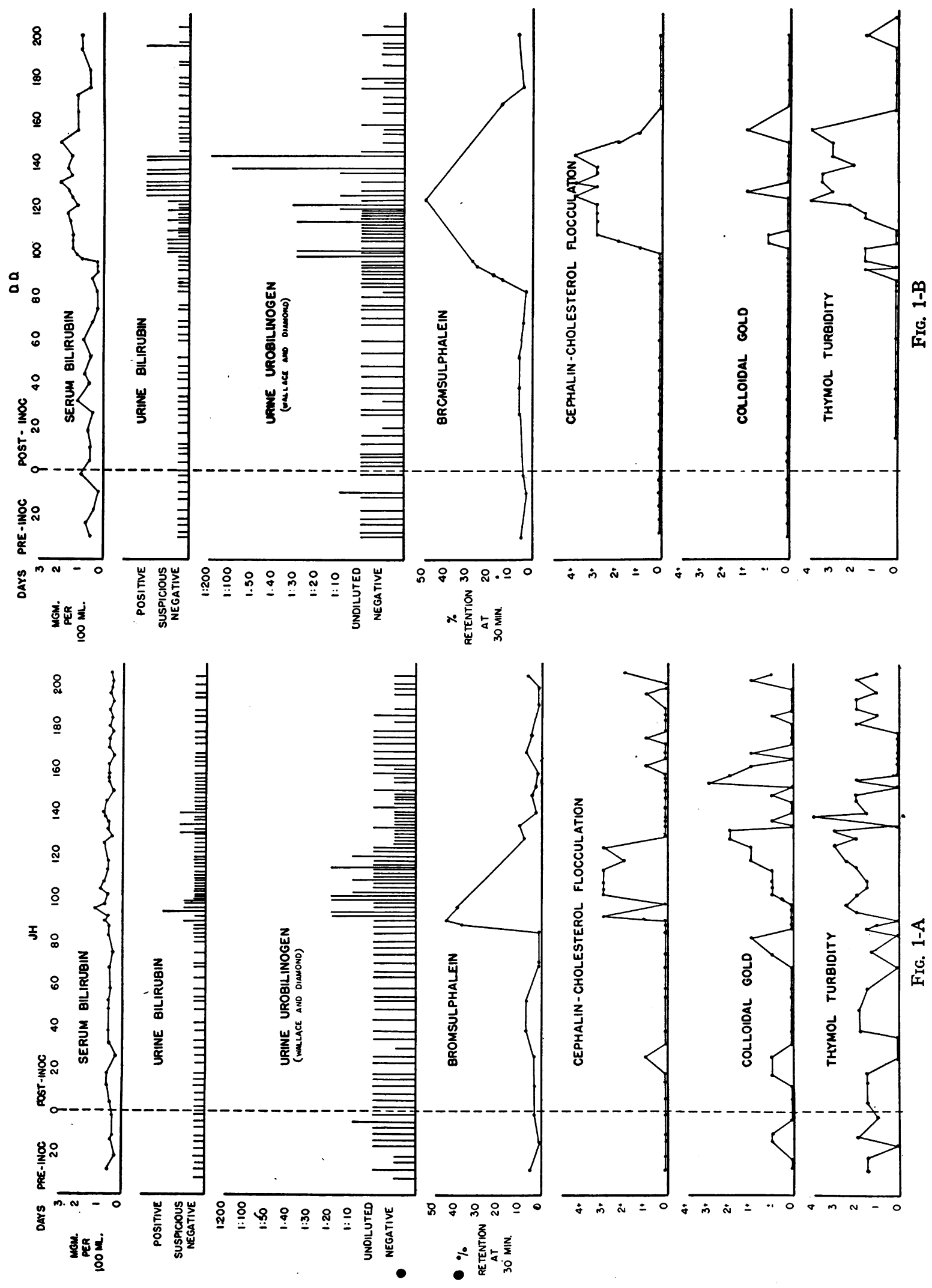


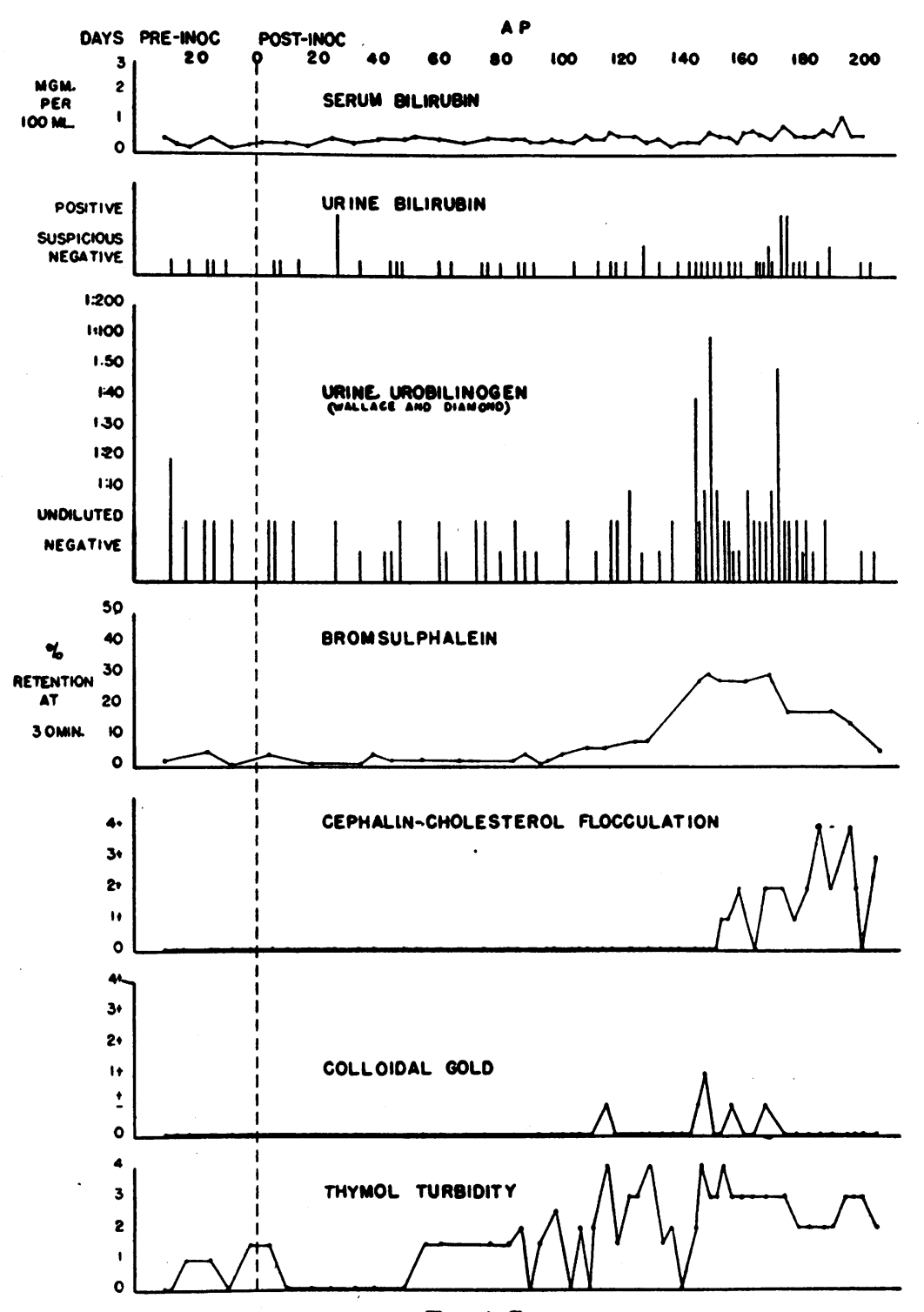

Fig. 1-C

Fig. 1 A, B, C. Laboratory Studies on the Three Volunteers Who Developed Laboratory Evidence of Hepatitis Following Their Inoculation with the Unheated Mixture of Icterogenic Plasma and Human Serum Albumin Solution

effectiveness of lower temperatures for the same period was not determined. Although the desirability of such experiments on a wider scale is evident, it was impossible to obtain larger groups of volunteers.

\section{DISCUSSION}

The need for methods of inactivating the virus of hepatitis in blood and blood products has been emphasized by the report by Spurling et al. (2.) who investigated the incidence of homologous serum hepatitis in recipients of 400 different pools of serum and plasma provided by one London Blood Supply Depot. Jaundice developed in $7.3 \%$ of recipients of serum and plasma, but did not occur among an equal number of recipients of whole blood.

Recent evidence makes it clear that pooled 
plasma prepared from blood obtained in the United States is likewise frequently icterogenic. In a study made by the New York State Department of Health (14) the incidence of homologous serum jaundice following the administration of reconstituted dried plasma distributed by the American Red Cross has been approximately $4.5 \%$ of 649 patients on whom adequate data could be obtained. A study of the experience of a hospital blood bank, using frozen plasma, revealed at least 11 cases of serum jaundice in a year during which 949 units of pooled plasma and 1,494 units of whole blood were administered to patients (15).

These figures indicate that the fears concerning the danger of wide dissemination of homologous serum jaundice by normal human serum albumin are fully justified since the albumin was prepared from far larger pools than plasma and each lot was distributed to many more recipients. Because of these fears, studies of the effect of the plasma fractionation process on viruses were made. Bird, Enders, and Boyd (16) showed that viruses added to pooled plasma survived a small scale fractionation procedure in the laboratory. Theiler's mouse encephalomyelitis virus, vaccinia virus, tobacco mosaic virus, and tobacco necrosis virus were added to a small pool of plasma and fractionated to yield the major fractions. Titration of the viruses in the original plasma and in the fractions indicated that these viruses were neither destroyed nor concentrated in any particular fraction. Actual clinical experience has demonstrated that the use of fraction II (Gamma or immune serum globulin) in several thousand children has not been followed by hepatitis (17). Much less extensive experience with normal serum albumin has failed to reveal cases of hepatitis attributable to it. Nevertheless, the large size of the plasma pools from which plasma fractionation products are prepared, and the apparent lack of deleterious effect of the fractionation process on test viruses made imperative these studies on heat inactivation of the virus of homologous serum hepatitis in albumin solutions. Few experiments conducted up to the present time have been designed deliberately to inactivate or neutralize the hepatitis virus in whole blood, serum or plasma. Oliphant (18) has reported several studies in which a hepatitis virus in yellow fever vaccine or in serum apparently was inactivated by irradiation with ultra- violet light. Similar studies carried out by MacCallum (19) failed to confirm fully the work of Oliphant but the method employed appears promising and certainly deserves further investigation.

Stokes and his co-workers $(20,21)$ have prevented infectious (epidemic) hepatitis in men exposed to the disease by intramuscular injections of gamma globulin. The effect of gamma globulin is thought to be due to the presence of protective substances in the globulin. Less conclusive results in the protection by gamma globulin against homologous serum hepatitis $(22,23)$ may have been due to the administration of inadequate quantities of gamma globulin. Studies in volunteers now in progress may clarify further the role of gamma globulin in the prevention of homologous serum hepatitis (24).

Heating at $60^{\circ} \mathrm{C}$ for 10 hours is a practical procedure in the large scale preparation of human albumin solutions, and this step now is included in their routine preparation (12). It appears probable, therefore, that human albumin solutions so prepared will be free from the risk of viral hepatitis. Unfortunately, this method cannot be applied to serum or plasma, as coagulation occurs at $60^{\circ} \mathrm{C}$.

Although such heating does not seriously alter the properties of albumin solutions which have been properly stabilized it will lower the total duration of time during which the protein will withstand heating, particularly if any deviations from standard methods may have occurred during processing. Therefore, it would be desirable to know whether a shorter period of heating would regularly inactivate the virus or whether the process of fractionation itself regularly gives rise to a safe albumin solution. Unfortunately, the long incubation period of homologous serum hepatitis and the necessity for the use of human volunteers seriously handicap further studies on these questions.

\section{SUM MARY}

1. Because of the large size of the plasma pools used as starting material for the preparation of the products of plasma fractionation and because viruses added to plasma experimentally have been detected in all the major fractions obtained from it, contamination of solutions of normal human serum albumin with the virus of homologous 
serum hepatitis appears possible. Accordingly methods of inactivation of this virus in serum albumin were sought.

2. On the basis of limited experiments the virus of homologous serum hepatitis appeared to be inactivated when stabilized human albumin solutions to which the virus was added were heated at $60^{\circ} \mathrm{C}$ and $64^{\circ} \mathrm{C}$ for 10 hours. This degree and duration of heating apparently do not seriously alter the measurable chemical or physical properties of the albumin.

3. The minimum amount of heating required to inactivate this virus was not determined.

4. The method described is not applicable to whole blood, plasma, or serum.

5. Heat treatment at $60^{\circ} \mathrm{C}$ for 10 hours in the final container is now a routine step in the preparation of human albumin solutions. Clinical use of albumin so prepared would appear to be free from the risk of transmission of active serum hepatitis virus.

\section{BIBLIOGRAPHY}

1. Sawyer, W. A., Meyer, K. F., Eaton, M. D., Bauer, J. H., Putnam, P., and Schwentker, F. F., Jaundice in army personnel in the western region of the United States and its relation to vaccination against yellow fever. Am. J. Hyg., 1944, 39, 337.

2. Spurling, N., Shone, J., and Vaughan, J., The incidence, incubation period, and symptomatology of homologous serum jaundice. Brit. M. J., 1946, 1, 409.

3. Havens, W. P., Jr., Epidemiological studies on infectious hepatitis. Am. J. Pub. Health, 1946, 36, 37.

4. Neefe, J. R., Gellis, S. S., and Stokes, J., Jr., Homologous serum hepatitis and infectious (epidemic) hepatitis. Am. J. Med., 1946, 1, 3.

5. Neefe, J. R., Stokes, J., Jr., Reinhold, J. G., and Lukens, F. D. W., Hepatitis due to injection of homologous blood products in human volunteers. J. Clin. Invest., 1944, 23, 836.

6. Beeson, P. B., Chesney, G., and McFarlan, A. M., Hepatitis following injection of mumps convalescent plasma; reports from American Red CrossHarvard Field Hospital Unit; use of plasma in mumps epidemic. Lancet, 1944, 1, 814.

7. Ministry of Health (Memorandum prepared by medical officers of), Homologous serum jaundice. Lancet, 1943, 1, 83.

8. MacCallum, F. O., and Bauer, D. J., Homologous serum jaundice; transmission experiments with human volunteers. Lancet, 1944, 1, 622.
9. Neefe, J. R., Stokes, J., Jr., Baty, J. B., and Reinhold, J. G., Disinfection of water containing causative agent of infectious (epidemic) hepatitis. J. A. M. A., 1945, 128, 1076.

10. Ballou, G. A., Boyer, P. D., Luck, J. M., and Lum, F. G., Influence of non-polar anions on thermal stability of serum albumin. J. Clin. Invest., 1944, 23, 454.

11. Ballou, G. A., Boyer, P. D., Luck, J. M., and Lum, F. G., Heat coagulation of human serum albumin. J. Biol. Chem., 1944, 153, 589.

12. Scatchard, G., Strong, L. E., Hughes, W. L., Jr., Ashforth, J. N., and Sparrow, A. H., Chemical, clinical, and immunological studies on products of human plasma fractionation; properties of solutions of human serum albumin of low salt content. J. Clin. Invest., 1945, 24, 671.

13. Neefe, J. R., and Reinhold, J. G., Laboratory aids in the diagnosis and management of infectious (epidemic) hepatitis. Gastroenterology, 1946, 7, 393.

14. Brightman, I. J., and Korns, R. F., Homologous serum jaundice in recipients of pooled plasma. J. A. M. A., 1947, 135, 268.

15. Scheinberg, I. H., Kinney, T. D., and Janeway, C. A., Homologous serum jaundice. J. A. M. A., 1947, 134, 841.

16. Bird, K. T., Enders, J. F., and Boyd, W. C., Unpublished data.

17. Janeway, C. A., Personal communication.

18. Oliphant, J. W., Jaundice following administration of human serum; Harvey Lecture. Bull. N. Y. Acad. Med., 1944, 20, 429.

19. MacCallum, F. O., Homologous serum hepatitis. Proc. Roy. Soc. Med., 1946, 39, 655.

20. Stokes, J., Jr., and Neefe, J. R., Prevention and attenuation of infectious hepatitis by gamma globulin; preliminary note. J. A. M. A., 1945, 127, 144.

21. Gellis, S. S., Stokes, J., Jr., Brother, G. M., Hall, W. M., Gilmore, H. R., Beyer, E., and Morrissey, R. A., Use of human immune serum globulin (gamma globulin) in infectious (epidemic) hepatitis in the Mediterranean Theatre of operations; studies on prophylaxis in two epidemics of infectious hepatitis. J. A. M. A., 1945, 128, 1062.

22. Grossman, E. B., Stewart, S. G., and Stokes, J., Jr., Post-transfusion hepatitis in battle casualties and study of its prophylaxis by means of human immune serum globulin. J. A. M. A., 1945, 129, 991.

23. Neefe, J. R., Recent advantages in the knowledge of "Virus Hepatitis." Med. Clin. N. Amer., 1946, 30, 1407.

24. Neefe, J. R., Stokes, J., Jr., Blanchard, M., Jr., and Gellis, S. S., To be published. 